\title{
Transforming Education in Elementary School During the Pandemic Covid-19
}

\author{
Dyan E. Pamungkas ${ }^{1, *}$ Sukarman $^{2,}$ Sri Sulistiani ${ }^{2}$ \\ ${ }^{I}$ Elementary Education, STKIP Bina Insan Mandiri, Surabaya, Indonesia \\ ${ }^{2}$ Language and Literature Education, Universitas Negeri Surabaya, Indonesia \\ *Corresponding author: fiandyan45@gmail.com
}

\begin{abstract}
The temporary closure of educational institutions to withstand the spread of pandemic Covid-19 worldwide has affected millions of students, especially the education system in Indonesia. This research aims to analyze the online learning process, supporting factors, and inhibitory factors of teachers carrying out online learning during the COVID19 pandemic. Data obtained in the form of qualitative data that contains descriptions about the results of the study observation and teacher interviews on the use of online learning models in elementary school. The research was conducted at a public elementary school in Nganjuk. The result of this study is that the COVID-19 pandemic has had a major impact on the learning process, learning is usually done directly now transferred to online learning. Students feel tired to carry out learning. Online learning for primary school-age children is considered less effective. There are several factors supporting teachers online in the learning process is the availability of mobile phones, internet quotas, and a stable internet connection. In addition to the factors that support online learning, several factors inhibit teachers in online learning. The limiting factor is that not all students have mobile phones, and many parents are busy working.
\end{abstract}

Keywords: COVID-19, Transformation, Online learning

\section{INTRODUCTION}

The pandemic Covid-19, which has been popular in many countries, including Indonesia, has changed the pattern of community behavior in its daily activities. There is no exception to the world of education that then organizes teaching and learning activities from home from last March to a changing school year. The Ministry of Education and Culture, through a joint decree (SKB) of four ministers, has recently issued a new school year learning guide 2020/20201. One of the points in the Guide is the prohibition to conduct face-to-front teaching and learning activities in $94 \%$ of the Indonesian region in the red, orange, and yellow zones. In the region, learning can only be done online.

Similar complexity is also experienced by policy stakeholders, who are forced to pull forward a new education system, ten or even twenty years earlier. While the transformation of education is still constrained by the readiness of infrastructure and uptake of technology. COVID19 can be a moment for education to accelerate the transformation into technology-based education. Transforming the world of education is not about reacting to the role of educators and schools, but thus strengthening the role of each stakeholder. Because online learning or education based on its true technology should be able to accommodate the role of teachers, schools, and parents in the process of student education.

Online learning should also be able to bring interaction between them, to ensure that the character's education continues to run even when done virtually. "Online learning solutions are ideally not merely a center of literacy but also a platform that can accommodate learning systems in schools. That way, online learning can be a solution, because it complies to use during COVID19 or later, "

Educators must make sure that learning is running, even if learners are at home. The solution is that educators are required to design learning media as innovations by utilizing online media. This corresponds to the Minister of Education and Culture of the Republic of Indonesia related to circular letter number 4 in the year 2020 concerning the implementation of education policy in the emergency spread of Corona Virus Disease (Covid-19). 
The learning system is carried out through a personal computer (PC) device or a laptop connected to an Internet network connection. Educators can work together at the same time using groups on social media such as WhatsApp (WA), Telegram, Instagram, zoom apps, or any other media as a learning medium. As such, educators can make sure learners follow their learning at the same time, even in different places. Educators can also give measurable tasks by the purpose of the material presented to learners.

The Covid-19 pandemic condition resulted in tremendous change, entering into the field of education. As if all levels of education were ' forced ' transformed to be dramatically adapted to conduct learning from home through online media. This is certainly not an easy thing, because it is not fully prepared. The educational problems of education are not the same as the learning process, both standard and the quality of the learning achievement.

Various learning media applications are already available, both government and private. The government issued a circular letter from the Minister of Education and Culture No. 9/2018 on Learning House utilization. Private parties also provide online tutorings, such as the teacher's room, Zenius, Klassku, Kahoot, and others. This access can be utilized to develop knowledge and insight. It is necessary to increase the quality of human resources (SDM). The success of the country's development of one of its rejects is educational.

The responsibility of teachers is to cultivate highquality human resources that can compete with international standards. In Indonesia, education management is at the forefront. The success of education is in the hands of teachers. Teachers are individuals who are directly faced with students in the classroom [1]. Teachers play an important role in enhancing academic, professional knowledge, emotional maturity, morality, and spiritual qualities. To support all of this, we need high quality, proficient, and dedicated teachers to do our job.

Educators believe that millennials are familiar with digital life, even since birth has been exposed to this digital technology, students are very adaptable. Even by themselves, they can accomplish all the tasks of intelligent gadgets in the grip. There are challenges that educators must immediately adapt to the digital era. As educators turned out we must realize that only the science we want to give to learners, it turns out all things they can get from the grasp of their hands quickly. All information can they get from surfing the search engine even tutorials and explanations material, information, and warehouse science is very wide open on social media such as YouTube and so on.

First learners recorded on the board and then all classmates copied into their notebooks. Note the book until it expires. The teacher spoke wide length, participants heard until sleepy. Time has changed, then the way of educating needs to be adjusted to the era and the day. The era of learning gaps between students who are millennials and educators who are digital technology immigrants must be minimized.

Surely must be the reflection of a teacher and lecturer. I'm just smart and clever, Internet technology may be smarter even able to present and provide all sorts of information needed. So what is the role of educators distinguishing from intelligent gadgets at their grasp? Through the gadget, it seems more effective. Asking teachers and lecturers is no longer an option because Google and other search engines seem to respond more quickly.

However, the role of teachers and lecturers cannot be replaced by technology. Because teachers and lecturers are not merely sources of science but must be examples and examples that transfer characters and values. The physical existence of a teacher and lecturer is still needed by learners in the learning process because its function not only conveys material and transfer science but educates the character and teaches how to interpret and live life better. The thing that needs to be reflected, that the important thing in life such as responsibility, discipline, empathy to others, honest, hard work, mutual respect, love of fellow man, simplicity, sincerity, and others can not be found even in smart gadgets though. It is only derived from the character's transparency and habituation. That is the true role of teachers and lecturers who are in the Gugu and imitated that can not be replaced by any technology.

At the forefront of education, the teacher's job is teaching, education, providing guidance and guidance, training, providing assessments and evaluations to provide students with ideological and psychological support. The teaching process performed by teachers and students is usually done at school or by interacting directly without intermediate media. However, in recent months, the teacher's work has changed during the learning process, as epidemics have struck the world, including Indonesia. 
Pandemic COVID-19 which takes place suddenly requires an educational tool to maintain online learning. The current situation encourages people to innovate and adapt to use existing technology to support the learning process [2]. This approach requires educators and students to interact and transfer knowledge online. Online learning can use platforms such as applications, websites, social networks, and learning management systems [3]. These platforms can be used to support a variety of discussion technologies and other technologies supported knowledge transfers.

Learners are also easy to access through social media networks that have been created on a digital platform. Students are free to learn from anywhere and anytime. Also, with this digital monitoring platform for students to be easily included in monitoring class activity, discipline collecting assignments, logging student developments even deadline and scoring settings can be automatic. The reports are automatically saved in an online drive that can be accessed anytime and anywhere as long as there is internet access. It saves time, especially paperless in task collection.

Being an educator in the digital age faces this millennial generation challenged to build effective communication, not too long to speak One direction. So it is necessary to prepare the presentation to be fun, attractive design and even the appearance of fashion styles must not be boring, formal but casual so that more fresh also becomes a challenge. In addition to being practical and establishing the next effective communication is to have to utilize technology starting from simple things such as using the present list/automatic digital presences, sharing materials using the platform-based cloud computing technology so effective for teaching and facilitate learners to communicate with educators. Furthermore, many discussions by making small groups were given interesting questions to discuss together. This can be given after the educator delivers the material at the beginning of class. When the learners are allowed to browse and surf-related topics through credible and relevant sources. It's a challenge to create interactions between learners and groups so that the atmosphere of the discussion becomes more vivid. Surely this is also to improve the skill of speaking in front of people. Then provide relevant examples to help learners digest material more easily.

The health crisis caused by the outbreak of COVID19 also initiated online learning. Online Tsunami learning is almost happening around the world during the COVID-19 pandemic [4]. Teachers and educators are needed as important elements of teaching to undertake unprecedented massive migrations from traditional face-to-school education to online or distance education [5]. It is not confined to the 4.0 Industrial Revolution at present. Even if educators and students are in different places, online learning can effectively apply to learn [6]. So it can solve students ' delay problems in learning knowledge.

The success of teachers in online learning in COVID-19 pandemic situations is the ability of teachers to design innovations, and collect materials, teaching methods, and applications according to materials and methods. Creativity is the key to a teacher's success in being able to motivate students to stay in the spirit of learning online and not become a psychological burden.

Also, successful online learning during COVID 19 depends on the discipline of all parties. Therefore, schools/madrassas here need to create schemes by putting together good management in regulating online learning systems. This is done by creating a systematic, structured, and simple schedule to facilitate parental communication with the school their children are learning at home can be monitored effectively [7].

Thus, online learning as an effective solution in learning at home to break the Covid-19 chain, physical distancing (keeping a safe distance) is also a consideration of choosing to learn. Good cooperation between teachers, parents, students, and schools/madrassas becomes the deciding factor that online learning is more effective.

According to the Ministry of Education and Culture notice, even if the school is closed, teaching or learning activities have not ceased, all learning activities are conducted at home using an online learning system. Online learning is a learning that is done remotely through the media through the Internet and other supporting tools (such as mobile phones and computers). Online learning is very different from normal learning, online learning emphasizes the accuracy and foresight of students in receiving and processing information online [8]. Online learning concepts are the same as e-learning concepts. During online learning, many parents complained about some of the problems facing students while studying at home, including too many homework and teachers who have not yet optimized the technology. In addition to many complaints from parents about online learning, it turns out that learning also has many advantages. As for some advantages of online learning, namely, the flexibility of 
time and place of study, for example, you can study indoors, living rooms, etc., or you can adjust the time in the morning, noon, afternoon, or evening.

Can overcome the problem of distance, for example, students do not have to go to school to study first. There is no limit, it can cover a large area. In addition to the advantages of online learning, online learning also has weaknesses. The excellence of online learning is to build a new learning atmosphere, online learning will bring a new atmosphere for students who usually study in the class [9]. A new mood can foster students ' enthusiasm for learning. As for some shortcomings in online learning, it is difficult for children to concentrate on learning because the family atmosphere is not conducive to children. Internet quota or limited Internet or WiFi software packages, and many online learning disruptions and a few other things. Online learning leads to a lack of interaction between teachers and students, and even between students. Lack of interaction will delay the formation of values in the teaching process. Ongoing online learning is a new thing that teachers and students are feeling [10].

Based on the problems described above, researchers are encouraged to describe the teacher's online learning process during the COVID-19 pandemic and to outline the supporting factors and barriers during the teacher's online learning process during the COVID-19 pandemic. Therefore, researchers will learn the ways and methods of the online learning process of elementary school teachers based on the analysis of SDN Sambirejo III Nganjuk during the COVID-19 pandemic.

\section{METHOD}

The type of research used in this study is a qualitative descriptive. Method qualitative descriptive method as a method or exploration to explore and understand the central phenomenon. Qualitative research results in the field of education are descriptive [11]. The purpose of qualitative research is to understand the individual's views, find and explain the process, and explore the depth of information about the subject or background of limited research [12]. T The research population is all students of SDN Sambirejo III Nganjuk whose learning process uses online methods. The sample of 30 first- to sixth-graders was sampled. In selecting research objects, researchers use deliberate sampling techniques. Sampling aims to be "sampling techniques with certain considerations" [13]. The motivation for the selection of the theme is because the purpose of this research is how and what factors the online learning process (online) supports and inhibits teachers in the online learning process of elementary school teachers.

Good instruments also produce good data. The tools used in this study are in the form of interview guidelines, questionnaires, and documents given to elementary school teachers. Data collection technologies are activities undertaken by researchers to obtain data for research. The data collection techniques used in this study are in the form of interviews, polls, or polls and documents. The types of interviews used in this study were semi-structured interviews.

The type of questionnaire used in this study was an open questionnaire. An open questionnaire is a questionnaire that contains questions or statements, which can be filled freely by the interviewed person. This document records past events. The File can be text, image, or a person's anniversary [14]. The data analysis techniques used by researchers are the analysis techniques of Miles and Huberman. Qualitative data analysis activities should be carried out interactively and continued until completion so that the data becomes saturated. There are three activities in the data analysis, data reduction, data display, and conclude/verification [15].

At the data reduction stage, there is a lot of data obtained in the location, therefore it needs to be noted carefully. Reducing data means summarizing, picking points, focusing on important things, discovering topics and patterns, and eliminating unnecessary things. Data reduction will provide clearer images and facilitate researchers to do further collection and retrieval of data if needed. Then the final stage of drawing/verifying based on the content of a qualitative study that has been understood may be able to answer the question posed at the beginning, or may not be able to answer. This happens because qualitative research is still temporary and will be developed later in the field.

The research procedure used in the study is divided into three phases, namely the pre-field stage, the stage of fieldwork, and the data analysis stage. At the precourse stage, at this stage, the researchers compiled a design of research in the form of an understanding of the methods and techniques of research. Selection of field research, search and field evaluation in the form of positioning and field objectives so that researchers can try to identify all elements of the social environment, natural and natural conditions, and the introduction of this field is also aimed at assessing the situation, 
situation, environment and whether the background meets the question, prepare research equipment in the form of necessary research or research equipment, such as research licenses, In this stage of fieldwork, researchers first understand the background of research. Researchers need to be ready to start research to get the data or information needed for research. The Data obtained comes from survey surveys and interviews with elementary school teachers at designated research locations. Researchers analyzed to gain deeper results on the online learning process conducted by elementary school teachers during the COVID-19 pandemic, and what factors and contributing factors prevented teachers from implementing online learning? COVID-19 pandemic period.

After obtaining the data, the researchers will perform descriptive and deep editing of the data to conduct a good study of the data obtained. At the data analysis stage, in qualitative research, the data obtained comes from various data sources collected through various data collection techniques and continues until the data is saturated. Analysis of data conducted by researchers is to process the data collected or obtained in the field, in the form of information or the document at the previous stage, and then collect it into a research report.

\section{RESULTS AND DISCUSSION}

The study on the problematic use of google classroom as a means of learning on the motivation of science learning is not the first study, especially journal research or thesis. As far as research is concerned, the purpose of the study is to investigate the problematic application of google classroom as a means of learning to the motivation of high school students majoring in science, following a study relevant to the research that the author selected as a reference.

Based on the research results obtained from public questionnaires and semi-structured interviews conducted online. Questionnaires are distributed online through Google Forms, while interviews are made using WhatsApp. The results of the research obtained in this study are as follows.

\subsection{Questionnaire}

Questionnaires have been distributed to all teachers at SDN Sambirejo III. The questionnaire used in this study was an open questionnaire, in which an open questionnaire was a questionnaire filled by respondents. The purpose of using this questionnaire is to obtain information in the form of information, to implement the learning process and supporting factors in the network (online) during the COVID-19 pandemic, and to prohibit the teacher from online implementation during the COVID-19 pandemic at SDN Sambirejo III. The learning process. Here is the answer is given by the person interviewed.

(1) During a COVID-19 pandemic, do you implement an online learning process? If so, how does the process of implementing the online learning process during a COVID-19 pandemic?

"Yes, I am doing online learning. I also follow the instruction of the Minister of Education and culture to guide the students watching TVRI, and then the student fills the question given by the TVRI broadcast, and then report it to the rest of the class. "(PT Guru grade V SDN Sambirejo III)

"Every day according to plan" (Prosen Teacher Learning class IV)

(2) During a COVID-19 pandemic, are there any factors that support teacher teaching activities? Mention these supporting factors!

"There is a computer, mobile phone, quota, TV. " (SM teacher grade IV SDN Sambirejo III)

"Android phone and Quota" (Learning process IV)

(3) During a COVID-19 pandemic, is there a factor that inhibits teacher teaching activities? Mention factors this inhibitory!

"1. Students do not have all 2 phones. Parents are busy with 3 jobs. Quota limitation "(PT Guru grade V SDN Sambirejo III).

\subsection{Interview}

The interviews used in this study were semistructured interviews with two of the main interviewees, i.e. V-class teachers and class teachers from SDN Sambirejo III. The purpose of the interview is to deepen the data obtained from the questionnaire. The interview results of two interviewed people are as follows.

(1) During a COVID-19 pandemic, do you implement an online learning process? If yes, what steps do you take to implement the online learning process during the COVID-19 pandemic? 
"Yes, online learning is carried out during a pandemic. In some materials that need to be studied (for example, Learning mathematics), procedures are done through the layout via video call or voice explanation. The reason is that the teacher can not only learn the material written in the notes or through writing. Use WhatsApp as a media liaison between teachers and students. Assign and collect tasks through the Whatsapp group. Sometimes tasks are inconsistent with important learning materials, and some assignments are assigned to students. Prizes are not set, and sometimes the given material is repeated. While studying online, students will only repeat that much, without providing explanatory material. By the way, when the next day there is an order to study the learning materials delivered online, this has become a habit, when the material must be completed two months before completing the exam so that in the next two months teachers and students only need to repeat and strengthen the final exam material so they do not pursue the learning materials. In this online learning process, all completed tasks must be written in the same book. Learning also corresponds to the curriculum. There is no difference in using lesson plans in the online learning process, and everything is normal. "(AM Master Class V SDN Sambirejo III).

(2) During a COVID-19 pandemic, are there any factors that support teacher teaching activities? Mention these supporting factors!

"The supporting factor is the pulse must be there, and the quota must be full. There are an Android phone and enough internet quota. Because if it is limited by quota, the student will be giddy. Because learning to use an Internet connection. "(Process Learning teacher class V).

(3) During a COVID-19 pandemic, is there a factor that inhibits teacher teaching activities? Mention this inhibitory factor!

"The inhibitory factor in the online learning process is, first of all, not all students have a personal phone. Of the 28 students in the class, about 25 had only a personal phone, and the rest did not have their phone. The second factor though they have their phones or pupils that do not follow the rules set, they are also lazy, for example, the teacher begins to assign the assignment starting at 08.30 AM, students suddenly send or collect assignments, and sometimes do not even know what time to late at night or cross the border to allocate timing. The third factor is that the material is not complete when doing online learning, which is different from direct learning, for example, when learning online learners struggle only on one task and can not transfer to the next task, it will make it difficult for the teacher to move to the next in the study material is because everything is not finished. ". " (Process of learning Teacher's class V).

Based on the research results of qualitative descriptive methods, through the data collection technology, through the form of survey questionnaires and interviews with teachers of SDN Sambirejo III, they learned about the online learning process (online) and supporting factors for teachers in online learning and inhibitors. During the COVID-19 pandemic, it can be concluded that the COVID-19 pandemic strongly affects the educational community. This epidemic has caused a major disruption in the learning process, which is usually done face-to-face between teachers and students in the classroom during a period when the learning epidemic is converted into online learning. The teacher reveals that there are still many obstacles for students to learn online. The student participation rate in online learning has not reached $100 \%$. Some students are not even involved in learning from start to finish so that the teacher is confused during the student evaluation process. The online learning process is done according to the scheduled study time. Guru uses WhatsApp for online learning, and WhatsApp is used as a media guru to provide materials or send homework to students. Also reveals that online learning can use digital technology, but what to do is do the homework through the teachers through the guidance and monitoring of the WhatsApp group, so that the children can learn [16]. Teachers should also coordinate with parents through video calls and photos of children's learning activities at home to ensure interactions between teachers and parents. Teachers also make video calls to some learning materials, which need a straightforward explanation.

Also, in cases where homework is sometimes not done according to the required material, it is because online learning complicates teachers to transfer from one material to another, but the teacher tries to provide a suitable homework for students and the teacher manual. In effect, the impact the students are experiencing is that they are very tired of learning. The enthusiasm and enthusiasm shown by the students decreased every day. This situation differs from the situation where students and friends study in the class [17]. Another impact of the COVID-19 pandemic in students is that the school is closed for too long, so children are bored, children start to feel bored at home, want to go to school immediately play with friends, students are accustomed to learning to interact with his friends in school, play and joke with his 
friends, and meet face. Teachers also assess students ' sense of responsibility when they can follow their learning and fill out a list of online learning participants.

Students often complain that because they only give their children a constant lesson teachers are also uncomfortable because they cannot directly provide learning materials to students, but can only do homework. The way to cope with this tedious way is for teachers to actively provide interesting learning media, such as videos, but most online learning teachers also face obstacles or limitations when using learning media. The evaluation process performed by the teacher also has a system similar to the usual learning evaluation system.

When students collect homework, teachers will also directly evaluate online learning, and all subjects will also have the same evaluation. And it only has the effectiveness of about $75 \%$, so online learning for elementary school students will not be so effective. Online learning is possible because there are several supporting factors such as mobile phone, pulse, quota, and a steady and good Internet network. Mobile is a major contributing factor to online learning because, without cellular, online learning will not be completed. Also shows that this facility is very important for the smooth learning process, such as laptops, computers, or mobile phones, which will make it easy for teachers to provide online teaching and learning materials [18]. Teachers use online learning support factors by finding learning media in the form of videos to maximize their use, and to offset the development or progress of parental participation in online learning reported by students through the group of WhatsApp. Also, teachers give students the information or things they need in their studies.

In addition to the factors that support the implementation of online learning, there are several inhibitory factors in online learning. This is because online learning is a new thing for teachers. A distant learning method makes teachers need time to adapt, and they are faced with new changes that will indirectly affect the quality of learning outcomes [19]. The sender includes that not all students have a mobile phone. The next factor is that students will feel lazy when completing a task, even if it is already supported by a learning-supportive facility. The next factor is there are still many parents who work so that they cannot guide students fully in their learning.

There are several ways to overcome these constraints, including starting to provide information before learning so that everything is ready to follow while learning. The next step is to work with the class committees that are associated with students who don't have a cell phone so they can ask friends who are close to home so they can share their learning. Besides busy parents working, teachers also simplify the collection of homework.

Online learning is also inseparable from parents ' roles because, given the age of elementary school children, they still need the guidance and supervision of learning. Parents are always providing new information about the growth of their children in online learning. In online learning, students desperately need a teacher's motivation to keep the spirit of learning. The way teachers are motivated is to provide interesting and interesting homework. All teachers have made videos to encourage students, even if they have to study at home.

\section{CONCLUSION}

Based on the results of the research conducted through qualitative descriptive methods through data collection techniques, this technique surveyed teachers of SDN Sambirejo III in the form of questionnaires and interviews. Pandemic COVID-19 had a huge impact on education, especially in the learning process undertaken by teachers. The learning process carried out by the teacher has changed, usually by directly learning to become online learning. It is believed that online learning does not affect teachers, especially elementary school-age children, because online learning is a learning method, and teachers do not maximize the use of learning materials, thus making the ingredients incomplete and in online learning, feeling using learning media is not optimal. Learners are also bored with online learning, they are bored with doing their homework every day. Students are too lazy to do homework, which makes the collection of homework late, making it difficult for teachers to evaluate. The evaluation process provided by the teacher is the same as the usual learning system. There are several contributing factors in online learning, including mobile phones, quotas, and a stable internet network.

These supporting factors will be used by teachers as much as possible to monitor the progress of students applying online learning. In addition to supporting factors, teachers also encountered obstacles in learning, for example, not all students have a cell phone, and many parents are busy working. Parents become very important people in the implementation of online learning because parents directly participate in the 
guidance and learning guidance of students. Motivation is very meaningful to students, the goal of this is to make students eager back even if they are studying at home.

\section{REFERENCES}

[1] S. Ahmed, M. Shehata, \& M.Hassanien, "Emerging faculty needs for enhancing student engagement on a virtual platform," MedEdPublish, pp 1-5. Available: https://doi.org/https://doi.org/10.15694/mep.2020.0 $00075.1,2020$

[2] S. Ahmed, M. Shehata, \& M.Hassanien, "Emerging Faculty Needs for Enhancing Student Engagement on a Virtual Platform," MedEdPublish, pp 1-5, Available: https://doi.org/https://doi.org/10.15694/mep.2020.0 00075.1. 2020

[3] Gunawan, Suranti, NMY. \& Fathoroni, "Variations of models and learning platforms for prospective teachers during the covid-19 pandemic period," Indonesian Journal of Teacher Education. 1 (2), 61-70. Available: https://journal.publicationcenter.com/index.php/ijte/article/view/95/48, 2020.

[4] K. Goldschmidt, \& P. D. Msn, The COVID-19 pandemic: Technology used to support the wellbeing of children. Journal of Pediatric Nursing, xxxx, 3-5. Available: https://doi.org/10.1016/j.pedn.2020.04.013. 2020.

[5] W. Bao, "COVID-19 and online teaching in higher education : a case study of Peking University," March, 113-115, 2020. Available: https://doi.org/10.1002/hbe2.191. 2020.

[6] G. Basilaia, \& D. Kvavadze, "Transition to online education in schools during a SARS-CoV-2 Coronavirus (COVID-19) pandemic in Georgia," Pedagogical Research, 5(4). Available: https://doi.org/10.29333/pr/7937, 2020.

[7] R. Sucilestari, \& K.. Arizona, "Peningkatan kecakapan hidup melalui pembelajaran sains berbasis proyek," Prosiding Seminar Nasional Pendidikan Biologi, pp 436-441. Available: http://www.jurnalfkip.unram.ac.id/index.php/Semn asBIO/article/view/700, 2018.
[8] Riyana, Pembelajaran Aktif, Inovatif, Kreatif, Efektif, dan Menyenangkan. Bandung: PT Geneshindo, 2019.

[9] P. Sari, "Memotivasi belajar dengan menggunakan e-learning. Jurnal Ummul Quro, 6(2), 20-35. Available:

http://ejournal.kopertais4.or.id/index.php/qura/issu e/view/531, 2015.

[10]L. Hadisi, \& W. Muna, "Pengelolaan teknologi informasi dalam menciptakan model inovasi pembelajaran (e-learning)," Jurnal Al-Ta'dib, 8(1), 117-140. Available: https://doi.org/10.31332/ATDB.V8I1.396, 2015.

[11]C. R. Semiawan, Metode Penelitian Kualitatif. Jakarta:Grasindo, 2010.

[12]N. Putra, Metode Penelitian Kualitatif Pendidikan. Rajawali Pers. 2013.

[13] Sugiyono, Metode Penelitian Kuantitatif Kualitatif, dan $R \& D$. Bandung: Alfabeta, 2015.

[14] Sugiyono, Metode Penelitian Kuantitatif Kualitatif, dan $R \& D$. Bandung: Alfabeta, 2014

[15]S. Arikunto, Prosedur Penelitian Suatu pendekatan Praktek. Jakarta: Rineka Cipta. 2003.

[16] A. Purwanto, R. Pramono, M. Asbari, P. B. Santoso, L. M. Wijayanti, C. C. Hyun, \& R. S. Putri, "Studi eksploratif dampak pandemi covid-19 terhadap proses pembelajaran online di Sekolah Dasar," Journal of Education, Psychology and Counseling, 2(1), 1-12, 2020.

[17] A. Purwanto, R. Pramono, M. Asbari, P. B Santoso, L. M. Wijayanti, C. C. Hyun, \& R. S. Putri, "Studi eksploratif dampak pandemi covid-19 terhadap proses pembelajaran online di Sekolah Dasar," Journal of Education, Psychology and Counseling, 2(1), 1-12, 2020.

[18] A. Purwanto, R. Pramono, M. Asbari, P. B. Santoso, L. M. Wijayanti, C. C. Hyun, \& R. S. Putri, "Studi eksploratif dampak pandemi covid-19 terhadap proses pembelajaran online di Sekolah Dasar," Journal of Education, Psychology and Counseling, 2(1), 1-12, 2020.

[19]L. Hadisi, \& W. Muna, "Pengelolaan teknologi informasi dalam menciptakan model inovasi pembelajaran (e-learning)," Jurnal Al-Ta'dib, 8(1),

$117-140$. Available: https://doi.org/10.31332/ATDB.V8I1.396, 2015. 